\title{
PENGARUH JUMLAH PEMBERIAN AIR DENGAN SISTEM IRIGASI TETES TERHADAP PERTUMBUHAN DAN HASIL TANAMAN TERUNG UNGU (Solanum melongena L.)
}

\author{
Fuzi Lestari Rezky ${ }^{1}$
}

${ }^{1}$ Program Studi Agroteknologi, Fakultas Pertanian, Universitas Andalas, Kampus Universitas Andalas, Limau Manis, Padang. Telp: 0751-25163

\begin{abstract}
ABSTRAK
Irigasi tetes merupakan metode pemberian air tanaman secara kontiniu dan penggunaan air yang sesuai dengan kebutuhan tanaman. Penelitian mengenai pengaruh jumlah pemberian air dengan sistem irigasi tetes terhadap pertumbuhan dan hasil tanaman terung ungu telah dilakukan pada bulan Februari-Mei 2017 di Rumah Kawat Kebun Percobaan Universitas Andalas, Limau Manis, Padang. Tujuan penelitian ini untuk mengetahui jumlah pemberian air yang terbaik dari air penyiraman selama periode pertumbuhan tanaman terung dengan menggunakan sistem irigasi tetes. Penelitian ini dirancang menggunakan Rancangan Acak Lengkap (RAL) yang terdiri dari 4 taraf perlakuan $(150 \mathrm{ml}, 200 \mathrm{ml}, 250 \mathrm{ml}, 300 \mathrm{ml})$ dan 5 ulangan. Setiap satuan percobaan terdiri dari 6 tanaman terung, 4 diantaranya dijadikan sampel. Data hasil pengamatan dianalisis dengan uji $\mathrm{F}$ pada taraf 5\% dan jika $\mathrm{F}$ hitung perlakuan lebih besar daripada $\mathrm{F}$ tabel dilanjutkan dengan uji Duncan's New Multiple Range Test (DNMRT) taraf nyata 5\%. Hasil penelitian menunjukkan bahwa jumlah pemberian air $300 \mathrm{ml}$ memberikan pengaruh yang terbaik terhadap pertumbuhan dan hasil tanaman terung.
\end{abstract}

Kata kunci: : terung ungu, irigasi tetes, penyiraman, Solanum melongena

\begin{abstract}
Drip irrigation supply the water continuously to the plant as much as reguired. The experiment on the effect of water amount using drip irrigation systems drips on the growth and yield of purple eggplant was conducted of screen house of Faculty of Agriculture Andalas University during the period of February to May 2017. The objective of the experiment is to investigle the better amount of water for the growth and yield of eggplant. Treatments were arranged using Completely Randomized Design (CRD) with 4 treatments: $150 \mathrm{ml}, 200 \mathrm{ml}, 250 \mathrm{ml}$, and $300 \mathrm{ml}$ with 5 replications. Data were analyzed Statistically using F-test of $5 \%$ level, and if F-cal > F-table then followed by Duncan's New Multiple Range Test (DNMRT) at 5\% level. Results indicated that application of $300 \mathrm{ml}$ of water gave the better result on the growth and yield of eggplant.
\end{abstract}

Key words: Purple eggplant, drip irrigation, watering, Solanum melongena

\section{PENDAHULUAN}

Terung (Solanum melongena L.) merupakan tanaman asli daerah tropis yang diduga berasal dari Asia, terutama India dan Birma. Dari kawasan tersebut, terung kemudian disebarkan ke Cina pada abad ke-5, selanjutnya disebarluaskan ke Karibia, Afrika Tengah, Afrika Timur, Afrika Barat, Amerika Selatan, dan daerah tropis lainnya. Terung disebarkan pula ke negara-negara subtropis, seperti Spanyol dan negara lain dikawasan Eropa. 
Terung merupakan salah satu produk tanaman hortikultura yang sudah banyak tersebar di Indonesia. Dalam 100 gram terung ungu mentah mengandung 24 kalori, sedangkan 100 gram terung ungu rebus mengandung 35 kalori. Mengandung 9 gram karbohidrat, 1 gram protein, tidak mengandung lemak, tidak mengandung kolesterol, dan $239 \mathrm{mg}$ natrium (USDA 2010).

Permintaan komoditas terung akan terus meningkat seiring dengan pertambahan jumlah penduduk dan semakin meningkatnya kesadaran masyarakat terhadap kesehatan. Menurut Kementan (2014), produksi tanaman terung di Indonesia pada tahun 2014 yaitu 557.040 ton/ha mengalami kenaikan produksi sebesar $4,67 \%$ dengan luas panen tanaman terung sebesar 50.875 ha.

Meskipun produksi terung nasional tiap tahun cenderung meningkat namun produksi terung di Indonesia masih rendah dan hanya menyumbang $1 \%$ dari kebutuhan dunia (Simatupang 2010). Hal ini antara lain disebabkan oleh luas lahan budidaya terung yang masih sedikit dan bentuk kultur budidayanya masih bersifat sampingan dan belum intensif. Salah satu usaha yang dilakukan untuk meningkatkan produksi terung di Indonesia dapat ditempuh dengan memperbaiki teknik budidaya dan mengembangkan varietasvarietas yang memiliki daya hasil tinggi.

Dalam budidaya tanaman terung kondisi lingkungan yang dibutuhkan adalah dapat tumbuh di dataran rendah tinggi, suhu udara $22-30^{\circ} \mathrm{C}$, Jenis tanah yang paling baik, jenis lempung berpasir, subur, kaya bahan organik, aerasi dan drainase baik dan $\mathrm{pH}$ antara 6,8-7,3. Tanaman terung umumnya tumbuh baik di dataran tinggi dengan ketersediaan air yang mencukupi. Untuk budidaya terung di dataran rendah seringkali terjadi masalah dalam ketersediaan air. Kondisi ini menyebabkan muncul masalah kekeringan yang menjadi faktor pembatas produksi terung. Dari beberapa penelitian, upaya untuk mengatasi ketersediaan air bagi tanaman terung dilakukan melalui konservasi air dan tanah. Dalam konservasi air jumlah dan cara pemberian air ke tanaman tergantung pada jenis tanaman dan kondisi lingkungan. Agar tanaman dapat tumbuh dan mempunyai produktivitas yang optimal maka air harus diberikan dalam jumlah yang tepat.

Kebutuhan air tanaman terung yang didasarkan pada penelitian yang dilakukan oleh Frelindra (2015) yang menyatakan bahwa tingkat kebutuhan efektif air tanaman untuk pertumbuhan dan hasil produksi tanaman maksimal berkisar antara $60-80 \%$ dari kebutuhan air tanaman. Pada tingkat terpenuhinya kebutuhan air tanaman yang rendah $(<40$ $\%)$ ataupun pada terlampau tinggi (mendekati 100\%), tanaman tidak dapat berproduksi dengan baik. Metode yang dipakai dalam penelitiannya yaitu eksperimental murni yaitu tiga perlakuan pemberian air dan kebutuhan air terpenuhi $60 \%, 70 \%$, dan $80 \%$. Adapun hasilnya menunjukkan nilai pemberian air tanaman terung yang efektif dengan hasil produksi tanaman paling maksimal adalah dengan pemberian air terpenuhi $80 \%$ dari kebutuhan air tanaman terung dan total volume yang dapat dihemat selama periode pertumbuhan tanaman terung adalah sebesar 3,179 liter.

Bila jumlah air yang diberikan semakin banyak, kelebihan air menjadi tidak bermanfaat atau tidak efisien. Penurunan aktifitas fotosintesis berarti berkurangnya fotosintat yang cenderung mengakibatkan menurunnya jumlah bunga. Hal ini menyebabkan volume dan frekuensi penyiraman sangat perlu diperhatikan untuk menghasilkan cara penyiraman yang optimal (Kurnia 2004).

Dengan perkembangan teknologi pertanian yang sangat pesat menyebabkan kebutuhan air irigasi menjadi besar, keadaan dimana air sangat berharga menyebabkan sistem irigasi yang efisien sangat dibutuhkan. Salah satu cara irigasi yang memungkinkan dapat mengatur jumlah air sesuai dengan kebutuhan 
tanaman adalah irigasi tetes (Drip Irrigation). Sistem irigasi tetes dapat menghemat pemakaian air, karena dapat meminimumkan kehilangan kehilangan air yang mungkin terjadi seperti perkolasi, evaporasi dan aliran permukaan. Sistem irigasi yang banyak digunakan adalah irigasi curah di permukaan tanah. Irigasi ini membutuhkan air dalam jumlah banyak sedangkan tingkat efisiensi penggunaan airnya rendah. Untuk mengatasi keterbatasan air, sistem irigasi tetes merupakan pilihan tepat dalam meningkatkan efisiensi penggunaan air. Menurut Hadiutomo (2012), irigasi tetes adalah metode pemberian air pada tanaman secara langsung, baik pada areal perakaran tanaman maupun pada permukaan tanah melalui tetesan secara kontinu dan perlahan. Efisiensi penggunaan air dengan sistem irigasi tetes dapat mencapai $80-95 \%$. Cara pemberian irigasi yang tidak tepat menjadi penyebab utama rendahnya produktivitas tanaman terung.

Tujuan dari penelitian ini adalah untuk mengetahui jumlah pemberian air yang terbaik dari air penyiraman selama periode pertumbuhan tanaman terung ungu (Solanum melongena L.) dengan menggunakan sistem irigasi tetes.

\section{METODE PENELITIAN}

Penelitian berupa percobaan pot ini telah dilaksanakan pada bulan Februari sampai Mei 2017 bertempat di Rumah Kawat Kebun Percobaan Universitas Andalas, Limau Manis, Padang. Ketinggian lokasi adalah 385 meter di atas permukaan laut (mdpl) dengan jenis tanah yaitu Inceptisol.

Bahan yang digunakan adalah benih tanaman terung (Solanum melongena L.) varietas LEZATA F1cap panah merah, pupuk kandang sapi, pupuk phonska, air, dan tanah inceptisol.

Alat yang digunakan pada penelitian ini adalah polybag ukuran $10 \mathrm{~kg}$, botol aqua $600 \mathrm{ml}$, selang infuse, gelas ukur 500 ml, plastik bening, seedbad, label, cangkul, penggaris, thermometer, timbangan, jangka sorong, tiang standar, alat dokumentasi, dan alat tulis.

Rancangan yang digunakan dalam percobaan ini adalah Rancangan Acak Lengkap (RAL) dengan 4 taraf perlakuan dan 5 ulangan. Setiap satuan percobaan terdiri dari 20 tanaman dan 4 tanaman dijadikan sampel. Dimana 4 taraf perlakuan sebagai berikut:

- Jumlah air penyiraman $150 \mathrm{ml} / \mathrm{hari}$ (A)

- Jumlah air penyiraman $200 \mathrm{ml} / \mathrm{hari}$ (B)

- Jumlah air penyiraman $250 \mathrm{ml} / \mathrm{hari}$ (C)

- Jumlah air penyiraman $300 \mathrm{ml} / \mathrm{hari}$ (D)

Pelaksanaan penelitian ini dimulai dari persiapan tempat percobaan, persiapan media tanam, penyemaian benih, pemasangan label dan tiang standar, pemberian jumlah air penyiraman (perlakuan), dan penanaman bibit ke polybag. Sedangkan pemeliharaan tanaman meliputi penyiangan, penyulaman, pemasangan ajir, pemupukan, pengendalian hama dan penyakit, dan panen. Adapun variabel pengamatan meliputi: tinggi tanaman, jumlah daun, lebar daun, panjang daun terpanjang, umur muncul bunga pertama, jumlah bunga, umur panen pertama, panjang buah, diameter buah, jumlah buah pertanaman, total bobot buah pertanaman, rata-rata bobot buah pertanaman, dan satuan panas.

\section{HASIL DAN PEMBAHASAN}

\section{Tinggi Tanaman}

Berdasarkan Tabel 1, memperlihatkan bahwa jumlah air memberikan pengaruh terhadap tinggi tanaman terung ungu pada umur 49 HST. Tinggi tanaman dengan perlakuan jumlah air $300 \mathrm{ml}$ menunjukkan hasil tertinggi yaitu $54,76 \mathrm{~cm}$ dibandingkan dengan jumlah air $250 \mathrm{ml}$, 
$200 \mathrm{ml}$, dan $150 \mathrm{ml}$. Sedangkan perlakuan jumlah air $200 \mathrm{ml}$ dan $150 \mathrm{ml}$ menunjukkan hasil yang sama yaitu masing-masing 46,97 cm, dan 43,48 cm.

Tabel 1 Tinggi tanaman terung ungu dengan beberapa jumlah air penyiraman pada umur 49 HST

\begin{tabular}{cc}
\hline Jumlah air (ml) & $\begin{array}{c}\text { Tinggi tanaman } \\
(\mathbf{c m})\end{array}$ \\
\hline 300 & $54.76 \mathrm{a}$ \\
250 & $52.22 \mathrm{~b}$ \\
200 & $46.97 \mathrm{~b} \mathrm{c}$ \\
150 & $43.48 \quad \mathrm{c}$ \\
\hline
\end{tabular}

$\mathrm{KK}=1.842 \%$

Angka-angka pada kolom yang sama diikuti oleh huruf kecil yang sama berbeda tidak nyata menurut uji lanjut DNMRT taraf 5\%

Pertambahan pada tinggi tanaman terung ini diduga karena pengaruh yang timbul dari air itu sendiri. Hal ini sesuai dengan pernyataan Menurut Pudjiatmoko (2008), pada umumnya fase pertumbuhan membutuhkan suplai air untuk pertumbuhan batang dan daun sehingga kebutuhan airnya relatif besar. Menurut Syarief (2001), air yang cukup tersedia saat pertumbuhan tanaman mengakibatkan fotosintesis berjalan lebih aktif, sehingga proses pemanjangan, pembelahan dan differensiasi sel akan terjadi lebih baik yang dapat mendorong pertumbuhan tinggi tanaman.

Pada jumlah air $300 \mathrm{ml}$, pertambahan tinggi tanaman merupakan yang paling tinggi dibanding jumlah pemberian air yang lainnya. Diduga dengan jumlah air $300 \mathrm{ml}$, kebutuhan air untuk fase vegetatif tanaman telah tersedia dalam keadaan yang cukup. Sesuai pernyataan Zulkarnain (2009), dalam fase vegetatif terjadi pembelahan sel dan pemanjangan sel yang membutuhkan ketersediaan air yang cukup. Daerah pemebesaran sel berada tepat dibelakang titik tumbuh. Pada saat sel ini membesar, maka vakuola akan menghisap air dalam jumlah banyak. Akibatnya sel-sel akan mengalami pemanjangan dan penebalan pada dinding sel. Sehingga jika ketersediaan air tidak cukup maka akan menghambat proses pemanjangan sel.

\section{Jumlah Daun (helai)}

Berdasarkan Tabel 2, memperlihatkan bahwa jumlah air memberikan pengaruh terhadap jumlah daun tanaman terung ungu pada umur 49 HST. Jumlah daun dengan perlakuan jumlah air $300 \mathrm{ml}$ dan $250 \mathrm{ml}$ menunjukkan hasil yang sama dan lebih tinggi dengan perlakuan lainnya yaitu masing-masing 34,45 helai dan 31,55 helai. Sedangkan perlakuan jumlah air 200 $\mathrm{ml}$ dan $150 \mathrm{ml}$ juga menunjukkan hasil yang sama yaitu masing-masing yaitu 25,4 helai dan 22,5 helai.

Tabel 2 Jumlah daun tanaman terung ungu dengan beberapa jumlah air penyiraman pada umur 49 HST

\begin{tabular}{cc}
\hline Jumlah air (ml) & $\begin{array}{c}\text { Jumlah daun } \\
\text { (helai) }\end{array}$ \\
\hline 300 & $34.45 \mathrm{a}$ \\
250 & $31.55 \mathrm{a}$ \\
200 & $25.40 \mathrm{a} \mathrm{b}$ \\
150 & $22.50 \quad \mathrm{~b}$ \\
\hline
\end{tabular}

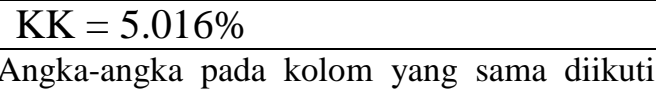
oleh huruf kecil yang sama berbeda tidak nyata menurut uji lanjut DNMRT taraf 5\%

Hal ini diduga karena pertambahan jumlah daun juga dipengaruhi oleh pertambahan tinggi tanaman. Berkaitan dengan variabel sebelumnya, jumlah pemberian air mempengaruhi pertambahan tinggi tanaman. Pada perlakuan jumlah air $300 \mathrm{ml}$, didapatkan jumlah daun terbanyak yaitu 34,45 pertanaman. Hal ini mengindikasikan bahwa ketersediaan air tercukupi pada jumlah air tersebut untuk pertumbuhan vegetatif tanaman. Hal ini akan sangat membantu tanaman dalam meregenerasikan sel-sel baru sehingga terjadi pemanjangan dan penebalan jaringan sesungguhnya seperti batang, daun dan akar. Menurut Zulkarnain (2009), bila ketersediaan air cukup maka akan mempercepat laju pembelahan sel, 
pemanjangan sel, dan pembentukan jaringan seperti batang, daun dan akar.

Hal ini juga diperkuat oleh pendapat Syarief (2001) menyatakan bahwa tinggi tanaman berkaitan dengan jumlah daun, dimana semakin tinggi tanaman semakin banyak daun yang terbentuk, karena daun keluar dari nodus-nodus yang ada pada batang.

\section{Lebar Daun (cm)}

Tabel 3 Lebar daun tanaman terung ungu dengan beberapa jumlah air penyiraman pada umur 49 HST

\begin{tabular}{cl}
\hline Jumlah air (ml) & $\begin{array}{c}\text { Lebar daun } \\
(\mathbf{c m})\end{array}$ \\
\hline 300 & $33.15 \mathrm{a}$ \\
250 & $31.70 \mathrm{~b}$ \\
200 & $30.77 \mathrm{~b}$ \\
150 & $29.39 \quad \mathrm{c}$ \\
\hline
\end{tabular}

$\mathrm{KK}=0.670 \%$

Angka-angka pada kolom yang sama diikuti oleh huruf kecil yang sama berbeda tidak nyata menurut uji lanjut DNMRT taraf 5\%

Berdasarkan Tabel 3, memperlihatkan bahwa jumlah pemberian air memberikan pengaruh terhadap lebar daun tanaman terung ungu pada umur 49 HST. Lebar daun dengan perlakuan jumlah air $300 \mathrm{ml}$ menunjukkan hasil yang terlebar yaitu $33,15 \mathrm{~cm}$ dibandingkan dengan jumlah air lainnya. Perlakuan dengan jumlah air 250 $\mathrm{ml}$ dan $200 \mathrm{ml}$ menunjukkan hasil yang sama yaitu masing-masing $31,70 \mathrm{~cm}$ dan $30,77 \mathrm{~cm}$. Pada perlakuan jumlah air 150 $\mathrm{ml}$ menunjukkan hasil terendah yaitu $29,39 \mathrm{~cm}$.

Lebar daun tanaman terung pada percobaan lebih lebar dibandingkan dengan lebar daun tanaman terung yang biasa dibudidayakan. Hal ini diduga selain adanya pengaruh jumlah pemberian air juga ada faktor lain yang cukup besar mempengaruhi pertambahan lebar daun yaitu intensitas cahaya.

Kondisi atap rumah kawat yang berlumut mengakibatkan intensitas cahaya yang diterima tanaman menjadi berkurang.
Hal ini dilihat pada lebar daun tanaman yang melebihi lebar daun normal. Ketersediaan cahaya dan air sangat mempengaruhi pertumbuhan dan perkembangan tanaman di setiap fasenya. Ketersediaan dalam jumlah yang cukup akan membantu memperlancar proses fotosintesis dan pengedaran fotosintat.

\section{Panjang Daun Terpanjang (cm)}

Tabel 4 Panjang daun terpanjang tanaman terung ungu dengan beberapa jumlah air penyiraman pada umur 49 HST

\begin{tabular}{cc}
\hline Jumlah air (m)) & $\begin{array}{c}\text { Panjang daun } \\
\text { terpanjang }(\mathbf{c m})\end{array}$ \\
\hline 300 & $45.34 \mathrm{a}$ \\
250 & $39.94 \quad \mathrm{~b}$ \\
200 & $37.90 \quad \mathrm{~b} \mathrm{c}$ \\
150 & $26.86 \quad \mathrm{c}$ \\
\hline
\end{tabular}

$\mathrm{KK}=1.213 \%$

Angka-angka pada kolom yang sama diikuti oleh huruf kecil yang sama berbeda tidak nyata menurut uji lanjut DNMRT taraf 5\%

Berdasarkan Tabel 4, memperlihatkan bahwa jumlah air memberikan pengaruh terhadap panjang daun terpanjang tanaman terung ungu pada umur 49 HST. Panjang daun terpanjang dengan perlakuan jumlah air $300 \mathrm{ml}$ menunjukkan hasil yang tertinggi yaitu $45,34 \mathrm{~cm}$ dibandingkan dengan jumlah air lainnya. Perlakuan dengan jumlah air $250 \mathrm{ml}$ dan $200 \mathrm{ml}$ menunjukkan hasil yang sama dan lebih tinggi dari perlakuan $150 \mathrm{ml}$.

Hal ini berkaitan dengan variabel sebelumnya yaitu lebar daun. Dimana Panjang daun terpanjang daun terung lebih panjang bila dibandingkan dengan daun terung umumnya. Selain faktor ketersediaan air, faktor cahaya juga mempengaruhi perkembangan panjang daun. Dimana keduanya berpengaruh pada proses fotosintesis dan transportasi asimilat. Pada fase vegetatif tanaman, air dan cahaya mempengaruhi pembelahan sel dan perkembangan sel pada daun tanaman. 


\section{Umur Muncul Bunga Pertama (hari)}

Tabel 5 Umur muncul bunga pertama tanaman terung ungu dengan beberapa jumlah air penyiraman

\begin{tabular}{cc}
\hline Jumlah air (ml) & $\begin{array}{c}\text { Panjang daun } \\
\text { terpanjang }(\mathbf{c m})\end{array}$ \\
\hline 300 & $35.20 \mathrm{a}$ \\
250 & $33.20 \mathrm{~b}$ \\
200 & $31,60 \mathrm{c}$ \\
150 & $29.80 \quad \mathrm{~d}$ \\
\hline
\end{tabular}

$\mathrm{KK}=0.596 \%$

Angka-angka pada kolom yang sama diikuti oleh huruf kecil yang sama berbeda tidak nyata menurut uji lanjut DNMRT taraf 5\%

Berdasarkan Tabel 5, memperlihatkan bahwa jumlah air memberikan pengaruh terhadap umur muncul bunga pertama tanaman terung ungu. Perlakuan dengan jumlah air $300 \mathrm{ml}$ menunjukkan umur muncul bunga pertama yang paling lama yaitu 35,2 HST. Sedangkan umur muncul bunga pertama yang paling cepat yaitu pada perlakuan dengan jumlah air $150 \mathrm{ml}$ dengan umur 29,8 HST.

Hal ini diduga karena pada fase ini jumlah air yang diberikan mempengaruhi proses terbentuknya bunga. Dimana jika jumlah air semakin besar, maka umur muncul bunga semakin lama. Dan jika jumlah air semakin kecil, maka umur muncul bunga semakin cepat. Hal ini erat juga kaitannya dengan cekaman air pada proses penbentukan bunga. Jumin, 2008 menyatakan bahwa cekaman kekeringan atau kekurangan air menjelang pembungaan mempengaruhi sistem reproduksi dengan meningkatnya sterilitas bunga, kemudian pembungaan dan pembuahan akan gagal bila kekurangan air berlangsung lama.

\section{Jumlah Bunga}

Tabel 6 Jumlah bunga tanaman terung ungu dengan beberapa jumlah air penyiraman

\begin{tabular}{cl}
\hline Jumlah air (ml) & $\begin{array}{c}\text { Jumlah bunga } \\
(\mathbf{c m})\end{array}$ \\
\hline 300 & $29.17 \mathrm{a}$ \\
250 & $25.51 \mathrm{~b}$ \\
200 & $23.36 \mathrm{c}$ \\
150 & $20.61 \quad \mathrm{~d}$ \\
\hline
\end{tabular}

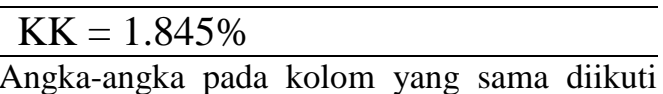
oleh huruf kecil yang sama berbeda tidak nyata menurut uji lanjut DNMRT taraf 5\%

Berdasarkan Tabel 6, memperlihatkan bahwa jumlah air memberikan pengaruh terhadap jumlah bunga tanaman terung ungu. Perlakuan dengan jumlah air $300 \mathrm{ml}$ menunjukkan jumlah bunga yang paling banyak yaitu 29,17. Sedangkan pada perlakuan jumlah air $150 \mathrm{ml}$ menunjukkan jumlah bunga lebih sedikit yaitu 20,61.

Pembungaan tanaman merupakan bagian yang tidak dapat dipisahkan dari pertumbuhan tanaman. Hal ini diduga karena adanya pengaruh faktor genetik, dimana ketika tanaman sudah memasuki fase generatif maka akan muncul bunga.

Taraf pemberian air yang rendah dalam jangka waktu yang lama menyebabkan jumlah bunga rendah. Menurut Pudjiatmoko (2008) kekurangan air yang berkepanjangan pada tanaman terung dapat mengganggu pertumbuhan stadia awal. Pecah- pecah pada buah terjadi apabila kekurangan air terjadi pada stadia pembentukan hasil dan menyebabkan kerontokan bunga apabila kekurangan air terjadi selama periode pembungaan. 


\section{Umur Panen Pertama (hari)}

Tabel 7 Umur panen pertama tanaman terung ungu dengan beberapa jumlah air penyiraman

\begin{tabular}{cc}
\hline Jumlah air (ml) & $\begin{array}{c}\text { Umur Panen } \\
\text { Pertama (hari) }\end{array}$ \\
\hline 300 & 62.40 \\
250 & 61.45 \\
200 & 60.00 \\
150 & 59.60 \\
\hline
\end{tabular}

$\mathrm{KK}=0.710 \%$

Angka-angka pada kolom yang sama berbeda tidak nyata menurut uji $\mathrm{F}$ taraf 5\%

Berdasarkan Tabel 7, memperlihatkan bahwa jumlah air memberikan pengaruh yang sama terhadap umur panen pertama tanaman terung ungu. Terung rata-rata dipanen pertama kali pada hari yang tidak jauh berbeda. Pada percobaan ini dengan perlakuan pemeberian jumlah air $300 \mathrm{ml}$ lebih lama umur panennya jika dibandingkan dengan varietas lezata f1 cap panah merah yaitu 55 - 60 HST.

Hal ini diduga erat kaitannya dengan tipe terung yang ditanam yaitu tipe determinate, yang artinya kuncup-kuncup bunga terbentuk di sepanjang ujung-ujung batang atau ketiak daun sehingga pucuk terminal tetap terus tumbuh secara vegetatif sampai hampir pertumbuhan akhir. Hal ini menyebabkan terung lebih banyak memproduksi pertumbuhan vegetatif dibandingkan tanaman yang bertipe indeterminate (Harjadi \& Yahya 2006).

\section{Panjang Buah (cm)}

Tabel 8 Panjang buah tanaman terung ungu dengan beberapa jumlah air penyiraman

\begin{tabular}{cc}
\hline Jumlah air (ml) & $\begin{array}{c}\text { Panjang Buah } \\
(\mathbf{c m})\end{array}$ \\
\hline 300 & 21.18 \\
250 & 19.05 \\
200 & 18.05 \\
150 & 17.58 \\
\hline $\mathrm{KK}=2.692 \%$ & \\
\hline
\end{tabular}

Angka-angka pada kolom yang sama berbeda tidak nyata menurut uji $\mathrm{F}$ taraf 5\%

Berdasarkan Tabel 8, memperlihatkan bahwa jumlah air memberikan pengaruh yang sama terhadap panjang buah tanaman terung ungu. Jika tanaman kekurangan air, maka proses pertumbuhan terhambat dan hasil akan menurun. Pada fase pembuahan kebutuhan air tanaman relatif tinggi karena air berhubungan dengan beberapa proses penting seperti regenerasi sel-sel, pendewasaan jaringan - jaringan, pembentukan hormon tertentu untuk perkembangan primordia bunga, perkembangan kuncup bunga, buah, dan biji.

Menurut Harjadi dan Yahya (2006) tanaman sangat membutuhkan air dalam jumlah yang teratur untuk mendukung pertumbuhannya, sehingga pemberian air yang merata sepanjang pertumbuhan tanaman akan selalu ideal untuk tanaman tersebut. Ketersediaan air tanah ditentukan oleh banyaknya air kapiler yaitu air yang berada di antara kapasitas lapang dan layu permanen.

\section{Diameter Buah (mm)}

Tabel 9 Diameter buah tanaman terung ungu dengan beberapa jumlah air penyiraman

\begin{tabular}{cc}
\hline Jumlah air (ml) & $\begin{array}{c}\text { Diameter buah } \\
(\mathbf{m m})\end{array}$ \\
\hline 300 & $33.92 \mathrm{a}$ \\
250 & $30.70 \mathrm{~b}$ \\
200 & $28.97 \mathrm{c}$ \\
150 & $27.32 \quad \mathrm{~d}$ \\
\hline $\mathrm{KK}=2.692 \%$ &
\end{tabular}

Angka-angka pada kolom yang sama diikuti oleh huruf kecil yang sama berbeda tidak nyata menurut uji lanjut DNMRT taraf 5\%

Berdasarkan Tabel 9, memperlihatkan bahwa jumlah air memberikan pengaruh terhadap diameter buah tanaman terung ungu. Diameter buah dengan perlakuan jumlah air $300 \mathrm{ml}$ menunjukkan hasil yang besar yaitu 33,92 $\mathrm{mm}$ dibandingkan dengan jumlah air $150 \mathrm{ml}$ yaitu $27,32 \mathrm{~mm}$. 
Hal ini menunjukkan bahwa semakin tinggi jumlah air penyiraman maka kualitas buah semakin baik. Jumlah air penyiraman $300 \mathrm{ml}$ meningkatkan diameter buah dan jumlah rongga buah sedikit. Boland et. al (1993) menyatakan jumlah air yang tepat mempercepat pertumbuhan sampai pembentukan ukuran buah.

\section{Jumlah Buah Pertanaman (buah)}

Tabel 10 Jumlah buah pertanaman (buah) tanaman terung ungu dengan beberapa jumlah air penyiraman

\begin{tabular}{cc}
\hline $\begin{array}{c}\text { Jumlah air } \\
(\mathbf{m l})\end{array}$ & $\begin{array}{c}\text { Jumlah buah } \\
\text { pertanaman } \\
\text { (buah) }\end{array}$ \\
\hline 300 & $21.17 \mathrm{a}$ \\
250 & $19.65 \mathrm{~b}$ \\
200 & $18.55 \mathrm{~b} \mathrm{c}$ \\
150 & $15.85 \quad \mathrm{~d}$ \\
\hline $\mathrm{KK}=1.450 \%$ &
\end{tabular}

Angka-angka pada kolom yang sama diikuti oleh huruf kecil yang sama berbeda tidak nyata menurut uji lanjut DNMRT taraf 5\%

Berdasarkan Tabel 10, memperlihatkan bahwa jumlah air memberikan pengaruh terhadap jumlah buah pertanaman tanaman terung ungu. Dapat diketahui bahwa jumlah buah pertanaman tanaman terung ungu pada jumlah air $300 \mathrm{ml}$ cenderung menunjukkan hasil yang lebih baik yaitu 21,17 buah dibandingkan dengan jumlah air $150 \mathrm{ml}$. Sedangkan hasil yang lebih sedikit perhitungan jumlah buah pertanaman terdapat pada jumlah air $150 \mathrm{ml}$ yaitu 15,85 buah.

Hal ini menunjukkan bahwa tanaman yang kekurangan air akan memicu pembentukan hormon penghambat asam absisat dan penghambat hormon perangsang pertumbuhan. Kondisi kekurangan air juga mengurangi air ketersediaan hara bagi tanaman karena jumlah air dalam tanah akan memperngaruhi konsentrasi hara dalam larutan tanah dan laju pergerakan hara ke akar melalui difusi dan transpor massa (Arifin, 2002).

Hal ini sebagai akibat dari cukupnya tingkat ketersediaan air bagi tanaman. Bagi tanaman air berfungsi sebagai pelarut, yaitu untuk melarutkan air yang diberikan maupun yang tersedia di dalam tanah, yang selanjutnya digunakan untuk proses fotosintesis (Harjadi dan Yahya 2008).

\section{Rata-rata Bobot Buah (gr)}

Tabel 11 Rata-rata Bobot Buah (gr) tanaman terung ungu dengan beberapa jumlah air penyiraman

\begin{tabular}{cc}
\hline Jumlah air (ml) & $\begin{array}{c}\text { Rata-rata bobot } \\
\text { buah }(\text { gr) }\end{array}$ \\
\hline 300 & $186.68 \mathrm{a}$ \\
250 & $170.92 \mathrm{~b}$ \\
200 & $156.50 \quad \mathrm{c}$ \\
150 & $126.65 \quad \mathrm{~d}$ \\
\hline
\end{tabular}

$\mathrm{KK}=1.328 \%$

Angka-angka pada kolom yang sama diikuti oleh huruf kecil yang sama berbeda tidak nyata menurut uji lanjut DNMRT taraf 5\%

Berdasarkan Tabel 11, memperlihatkan bahwa jumlah air memberikan pengaruh terhadap rat-rata bobot buah tanaman terung ungu. Dapat diketahui bahwa rat-rata bobot buah tanaman terung ungu pada jumlah air 300 ml cenderung menunjukkan hasil yang lebih baik dengan perlakuan lainnya yaitu 186,68 gr. Sedangkan perlakuan jumlah air $150 \mathrm{ml}$ menunjukkan hasil yang sedikit yaitu 126,65 gr. Pada percobaan ini dengan perlakuan pemberian jumlah air lebih besar bobot buahnya jika dibandingkan dengan varietas lezata f1 cap panah merah yaitu $90-100 \mathrm{gr} / \mathrm{buah}$.

Hal ini menunjukkan bahwa taraf pemberian air pada produksi dan kualitas buah, hanya berpengaruh terhadap bobot buah dan jumlah rongga buah. Semakin tinggi taraf pemberian air maka bobot buah semakin besar dan jumlah rongga buah semakin sedikit. Taraf pemberian air yang tinggi dapat meningkatkan produksi buah 
dan kualitas buah menjadi baik (Rudich and Luchinsky 1986).

\section{Total Bobot Buah Pertanaman (kg)}

Tabel 12 Total bobot buah pertanaman (kg) tanaman terung ungu dengan beberapa jumlah air penyiraman

\begin{tabular}{cc}
\hline $\begin{array}{c}\text { Jumlah air } \\
(\mathbf{m l})\end{array}$ & $\begin{array}{c}\text { Total bobot buah } \\
\text { pertanaman }(\mathbf{k g})\end{array}$ \\
\hline 300 & $3.95 \mathrm{a}$ \\
250 & $3.35 \mathrm{a} \mathrm{b}$ \\
200 & $2.91 \mathrm{~b} \mathrm{c}$ \\
150 & $2.66 \quad \mathrm{~d}$ \\
\hline
\end{tabular}

$\mathrm{KK}=1.096 \%$

Angka-angka pada kolom yang sama diikuti oleh huruf kecil yang sama berbeda tidak nyata menurut uji lanjut DNMRT taraf 5\%

Berdasarkan Tabel 11, memperlihatkan bahwa jumlah air memberikan pengaruh terhadap total bobot buah tanaman terung ungu. Dapat diketahui bahwa total bobot buah tanaman terung ungu pada jumlah air $300 \mathrm{ml}$ menunjukkan hasil yang lebih baik dibandingkan dengan perlakuan lainnya yaitu 3,95 kg. Menurut Isdarmanto (2009) berat buah dipengaruhi oleh kandungan air dalam buah. Dengan meningkatnya produktivitas metabolisme maka tanaman akan lebih banyak membutuhkan air dan meningkatkan penyerapan air, serta kebutuhan bagi tanaman pada masa pertumbuhan dan perkembangan.

Ritche (2006) menyatakan bahwa proses yang sensitif bisa terjadi sebagai dampak dari kekurangan air ialah pembelahan sel. Hal ini dapat diartikan bahwa pertumbuhan tanaman sengat peka terhadap defisit (cekaman) air karena dapat menghentikan pembelahan sel dan mengakibatkan tanaman lebih kecil.

\section{Satuan Panas}

Tabel 13 Satuan panas, umur muncul bunga pertama daan umur panen pertama tanaman terung ungu dengan beberapa jumlah air penyiraman

\begin{tabular}{ccc}
\hline Jumlah air (ml) & $\begin{array}{c}\text { Umur muncul bbunga } \\
\text { pertama (SP) }\end{array}$ & $\begin{array}{c}\text { Umur panen pertama } \\
\text { (SP) }\end{array}$ \\
\hline 300 & 363.9 & 878.9 \\
250 & 325.4 & 858.9 \\
200 & 288.4 & 838.9 \\
150 & 250.4 & 818.9 \\
\hline
\end{tabular}

Berdasarkan Tabel 13, memperlihatkan bahwa satuan panas pada umur muncul bunga pertama dengan pemberian perlakuan jumlah air $300 \mathrm{ml}$ menunjukkan hasil jumlah satuan panas tertinggi dibandingkan dengan perlakuan lainnya yaitu 363,9. Pada pemberian perlakuan jumlah air $150 \mathrm{ml}$ menunjukkan satuan panas terendah yaitu 250,4. Begitu pula pada umur panen pertama, dimana pemberian volume air $300 \mathrm{ml}$ menunjukkan jumlah satuan panas yang tertinggi yaitu 878,9. Pada pemberian perlakuan jumlah air 150 menunjukkan jumlah satuan panas terendah yaitu 818,9 .
Hal ini menunjukkan bahwa ada kecendrungan umur muncul bunga pertama dan umur panen pertama berdasarkan satuan panas ditentukan oleh volume air yang diberikan. Menurut Handoko, 2000 menyatakan pertumbuhan maupun perkembangan tanaman sangat ditentukan oleh unsur-unsur cuaca seperti suhu dan udara yang menjadi faktor yang paling berpengaruh.

\section{KESIMPULAN}

Berdasarkan penelitian yang telah dilakukan tentang pengaruh jumlah pemberian air dengan sistem irigasi tetes 
terhadap pertumbuhan dan hasil tanaman terung ungu (Solanum melongena L.), dapat disimpulkan bahwa perlakuan jumlah air dengan penyiraman $300 \mathrm{ml}$ memberikan pengaruh yang terbaik terhadap pertumbuhan dan hasil tanaman terung. Dari hasil penelitian yang telah dilakukan, maka dapat disarankan untuk menggunakan sistem irigasi tetes dengan jumlah air penyiraman $300 \mathrm{ml}$ dalam budidaya tanaman terung ungu.

\section{DAFTAR PUSTAKA}

Arifin. 2002. Produksi Tanaman Sayuran. Jakarta (ID): Soeroengan Djakarta.

Boland AM, Mitchell PD, Jerie PH, Goodwin I. 1993. The effects of regulated deficit irrigation on tree water use and growth of peach. Journal hort. Science. 68 (2): 261274.

Frelindra F. 2015. Studi Pola Pemberian Air Berdasarkan Efisiensi Pemakaian Air Pada Tanaman Terung Dengan Metode Irigasi Tetes. [skripsi]. Malang (ID): Universitas Brawijaya.

Hadiutomo. 2012. Mekanisasi Pertanian. Bogor (ID): IPB Press

Handoko. 2000. Dasar Penyusunan dan Aplikasi Model Simulasi Computer untuk Pertanian. Bogor (ID): Jurusan Geofisika dan Meteorologi, F-MIPA Institut Pertanian Bogor.

Harjadi dan Yahya SS. 2008. Pengantar Agronomi. Bogor (ID): Departemen Agronomi Fakultas Pertanian IPB. Bogor.

Harjadi, Yahya SS. 2006. Pengantar Agronomi. Bogor (ID): Departemen Agronomi Fakultas Pertanian IPB. Bogor.

Isdarmanto. 2009. Pengaruh Macam Pupuk Organik dan Kosentrasi Pupuk Daun Terhadap Pertumbuhan Dan Hasil Tanaman Cabai Merah (Capsicum annum L.) Dalam Budidaya Sistem Pot. [skripsi].
Surakarta (ID): Universitas Sebelas Maret.

Kurnia. 2004. Pengaruh cekaman air dan reaksi pemuliaan tanaman jagung dansorgum pada fase pertumbuhan vegetatif. Penelitian pertanian. 9(4): 148:151.

Pudjiatmoko. 2008. Budidaya Tomat (Lycopersicon esculentum). http://www.nusaku.com. Forum.xml. [11 Juli 2009].

Ritche JT. 2006. Climate and soil water, In Moving up the yield curve. Advace and obstacle, Spec. Publ. 39: 1-23.

Rudich J, Luchinsky U. 1986. The Tomato Crop. In: Atherton, J. G. and J.Rudich (Eds.). Water economy. New York (US): Chapman and Hall. Simatupang. 2010. Budidaya Terung. Jakarta (ID): Kanisius.

Syarief. 2001. Pengaruh cekaman air dan reaksi pemuliaan tanaman jagung dansorgum pada fase pertumbuhan vegetatif. Penelitian pertanian. 9(4):148-151.

USDA, 2010. Eggplant (Solanum melongena L.) Available at:http://plants.usda.gov/plantguide/ doc/pg_some.doc. Accessed at 08/27 2010

Zulkarnain H. 2009. Dasar - Dasar Hortikultura. Jakarta (ID): Bumi Aksara. 